УДК 37.046.16:061.18(477)

\title{
Анатолій Захарович ПІДГОРНИЙ
}

кандидат економічних наук, професор, завідувач кафедри статистики, Одеський національний економічний університет, e-mail: azp1@ukr.net

\section{Тетяна Сергіївна КОРОЛЬОВА}

кандидат економічних наук, старший науковий співробітник науково-дослідної частини,

Одеський національний економічний університет, e-mail: tckoroleva@ukr.net

\section{СОЦІАЛЬНО-ЕКОНОМІЧНІ УМОВИ ТА ЧИННИКИ НЕОБХІДНОСТІ ОПТИМІЗАЦІЇ СУЧАСНОЇ МЕРЕЖІ ВИЩИХ НАВЧАЛЬНИХ ЗАКЛАДІВ В УКРАЇНІ}

Підгорний, А. 3. Соціально-економічні умови та чинники необхідності оптимізації сучасної мережі вищих навчальних закладів в Україні / Анатолій Захарович Підгорний, Тетяна Сергївна Корольова // Вісник соціальноекономічних досліджень: зб. наук. праць; за ред. М. І. Звєрякова (голов. ред.) та ін. (ISSN 2313-4569). - Oдеса: Одеський національний економічний університет. - 2016. - Bun. 1. - № 60. - C. 77-85.

\begin{abstract}
Анотація. У статті досліджено вплив чинників на формування сучасної мережі ВНЗ в Украӥні, визначено об'єктивні та суб'єктивні чинники. Узагальнено думку фахівців щзодо перебудови мережі ВНЗ в Украйні $i$ визначено, щчо більшість авторів характеризують сучасну мережу вищих навчальних закладів як не ефективну i таку, що потребує реформування. Проаналізовано сучасну територіальну $i$ галузеву структуру вищих навчальних закладів, їх науково-педагогічний потенціал, обсяги підготовки фахівців. Визначено, шзо мережа ВНЗ Украӥни перенасичена філіями вищих навчальних закладів, які не мають необхідного науково-педагогічного потенціалу та матеріально-технічного забезпечення. Проведено розрахунки майбутньої чисельності студентів та викладачів $і$ на цій підставі сформульовано позиџію щуодо необхідності, напрямів $і$ шляхів оптимізації мережі ВНЗ. Запропоновано основні організаџійні заходи щэодо оптимізаціі мережі вищих навчальних закладів в Україні. Визначено позитивні та негативні наслідки ичих заходів.
\end{abstract}

Ключові слова: вищі навчальні заклади; науково-педагогічний персонал; реформування; оптимізація; мережа; абітурієнти; студенти; прогнозування; наслідки реформування.

\section{Анатолий Захарович ПОДГОРНЫЙ}

кандидат экономических наук, профессор, заведующий кафедрой статистики,

Одесский национальный экономический университет, e-mail: azp1@ukr.net

\section{Татьяна Сергеевна КОРОЛЕВА}

кандидат экономических наук, старший научный сотрудник научно-исследовательской части, Одесский национальньий экономический университет, e-mail: tckoroleva@ukr.net

\section{СОЦИАЛЬНО-ЭКОНОМИЧЕСКИЕ УСЛОВИЯ И ФАКТОРЫ НЕОБХОДИМОСТИ ОПТИМИЗАЦИИ СОВРЕМЕННОЙ СЕТИ ВЫСШИХ УЧЕБНЫХ ЗАВЕДЕНИЙ В УКРАИНЕ}

Подгорный, А. 3. Сочиально-экономические условия и факторы необходимости оптимизации современной сети выстих учебных заведений в Украине / Анатолий Захарович Подгорный, Татьяна Сергеевна Королева // Вестник сочиально-экономических исследований: сб. науч. трудов; под ред. М. И. Зверякова (глав. ред.) и др. (ISSN 2313-4569). Одесса: Одесский национальный экономический университет. - 2016. - Bылn. 1. - № 60. - C. 77-85.

\footnotetext{
Аннотация. В статье исследовано влияние факторов на формирование современной сети ВУЗов в Украине, определенны объективные и субъективные факторы. Обобщено мнение специалистов относительно перестройки сети ВУЗов в Украине и определенно, что большинство авторов считают современную сеть высших учебных заведений не эффективной и такой, которая нуждается в реформировании. Проанализирована современная территориальная и отраслевая структура высших учебных заведений, их научно-педагогический потенцииал, объемы подготовки специалистов. Определено, что сеть ВУЗов Украины перенасыщена филиалами высших учебных заведений, которые не имеют необходимого научно-педагогического потенциала и материальнотехнического обеспечения. Проведены расчеты будущей численности студентов и преподавателей и на этом
} 
основании сформулирована позищия относительно необходимости, направлений и путей оптимизации сети ВУЗов. Предложены основные организационные мероприятия относительно оптимизации сети выстих учебных заведений в Украине. Определены позитивные и негативные последствия этих мероприятий.

Ключевые слова: высшие учебные заведения; научно-педагогический персонал; реформирование; оптимизация; абитуриенты; студенты; прогнозирование; последствия реформирования.

\title{
Anatolij PODGORNYJ
}

PhD in Economics, Professor, Head of Statistics Department, Odessa National Economic University,e-mail: azp1@ukr.net

\section{Tetiana KOROLEVA}

PhD in Economics, Senior Research Fellow of Scientific and Research Department, Odessa National Economic University, e-mail: tckoroleva@ukr.net

\section{SOCIO-ECONOMIC CONDITIONS AND FACTORS NECESSARY FOR THE OPTIMIZATION OF THE MODERN NETWORK OF HIGHER EDUCATION INSTITUTIONS IN UKRAINE}

Podgornyj, A., Koroleva, T. (2016), Socio-economic conditions and factors necessary for the optimization of the network of higher education institutions in Ukraine. Ed.: M. Zveryakov (ed.-in-ch.) and others [Sotsialnoekonomichni umovy ta chynnyk neobkhidnosti modernizatsii suchasnoi merezhi vyshchykh navchalnykh zakladiv $v$ Ukraini; za red.: M. I. Zveriakova (gol. red.) ta in.], Socio-economic research bulletin; Visnik social'no-ekonomicnih doslidžen' (ISSN 2313-4569), Odessa National Economic University, Odessa, Issue 1, No. 60, pp. 77-85.

\begin{abstract}
The influence of factors on the formation of a modern network of higher education institutions in Ukraine is researched, objective and subjective factors are defined. Expert opinion on the restructuring of higher education institutions network in Ukraine is generalized, and it is specified that the majority of authors characterize modern network of higher education institutions as ineffective and as one that needs to be reformed. Modern territorial and sectoral structure of higher education institutions, their scientific and pedagogical potential, volume of specialists training are analyzed. It is defined that the network of higher education institutions in Ukraine is oversaturated with branches of higher educational institutions that do not have the necessary scientific and pedagogical potential, financial and technical support. The calculations of the future number of students and teachers are made, and on this basis, the standpoint on the need, directions and ways of optimization of the network of higher education institutions is formulated. The basic arrangements regarding the optimization of the network of higher education institutions in Ukraine are proposed. Positive and negative effects of these measures are determined.
\end{abstract}

Keywords: higher education institutions; scientific and pedagogical staff; reformation; optimization; applicants; students; forecasting; consequences of the reforming.

\section{JEL classification: 1210}

Постановка проблеми у загальному вигляді. Сучасна мережа вищих навчальних закладів (ВН3) України представляє собою складну систему закладів різного рівня, різних форм власності та підпорядкування, розташованих по всій території країни.

В 90-і роки минулого століття відбувалося по суті безконтрольне відкриття нових вищих навчальних закладів та перепрофілювання існуючих без урахування наукового, педагогічного, фінансового та матеріально-технічного потенціалу. Це стало причиною невиправданої насиченості країни вищими навчальними закладами університетського рівня (за європейською класифікацією). На кожен мільйон населення України сьогодні в середньому припадає 5,4 таких навчальних закладів проти 2,6 у 1990 році, що значно перевищує аналогічний показник в європейських країнах. Наприклад, у Франції він становить 1,4, в Італії-1,3, в Іспанії-1,4, в Польщі - 0,3.

У результаті склалася певна суперечність між вимогами сучасного розвитку суспільства до наявності певних фахівців з вищою освітою і реальною кількістю їх підготовки у ВНЗ, що й обумовлює необхідність реформування мережі вищих навчальних закладів.

Аналіз досліджень і публікацій останніх років. Серед науковців, які приділяють увагу проблемам реформування системи вищої освіти та оптимізації структури ВНЗ можна визначити 
В. Андрущенка, Я. Болюбаша, І. Вахович, В. Єфремова, В. Кременя, О. Лисенка [1-6]. Дослідники, як і керівники державних органів управління освітою, мають декілька підходів щодо реформування системи вищої освіти i, зокрема, мережі ВНЗ.

I. Вахович, наприклад, вважає, що «передувати процесу створення укрупнених регіональних університетів державної форми власності повинні грунтовна оцінка якості навчального процесу у діючих ВНЗ та їхніх філіалах, ретельне вивчення можливостей об'єднання у кожному регіоні за вертикальним, і лише згодом, горизонтальним принципом, широке обговорення в академічних і громадських колах» [2, с.106].

Погоджуючись в цілому з цією точкою зору та на підставі проведеного аналізу стану цієї проблеми зазначимо, що реформування вищої освіти передусім необхідно проводити не лише за прикладом зарубіжного досвіду, але й з урахуванням власного досвіду, традицій, ретельного осмислення можливостей і потреб суспільства, збереження та підвищення якості інтелектуального потенціалу країни [5-10].

Виділення невирішених раніше частин загальної проблеми. В країні вже багато років існує проблема щодо оптимізації мережі вищих навчальних закладів. Серед напрямів реформування мережі ВНЗ найширше розповсюдження набула пропозиція щодо скорочення кількості вищих навчальних закладів.

Основними аргументами на користь такого підходу є: наявність надто великої кількості університетів в країні порівняно з розвиненими країнами; розпорошення науковопедагогічного персоналу та дроблення тематики наукових досліджень та коштів на їх проведення; недостатнє державне фінансування вищої освіти, зокрема, для створення потужної матеріально-технічної бази у значній кількості ВНЗ; неефективність управління вищою освітою в умовах багатовідомчого підпорядкування ВНЗ та ін.

Як відомо, найбільш вагомим аргументом на користь неминучості скорочення кількості вищих навчальних закладів є демографічна криза кінця XX - початку XXI століття, наслідками якої, в контексті зазначеної проблеми, стало поступове скорочення учнів загальноосвітніх шкіл, а починаючі з 2008 р. - скорочення чисельності випускників шкіл, тобто потенційних абітурієнтів ВНЗ. I, як наслідок, відбувається майбутнє суттєве скорочення чисельності випускників середніх шкіл, незалежно від інших обставин, яке сприятиме скороченню кількості ВНЗ та перерозподілу абітурієнтів між закладами освіти різних областей країни.

Через це, одним із об’єктивних чинників, який визначає напрямки та кількісні характеристики реформування мережі вищих навчальних закладів в Україні, є демографічна ситуація, тому що хвиля збільшення чисельності студентів у 90-ті роки та на початку XXI століття зійшла нанівець, а демографічні можливості поповнення контингенту абітурієнтів вичерпалися.

Постановка завдання. Метою статті $€$ визначення потенціальної чисельності абітурієнтів ВНЗ на підставі прогнозних розрахунків чисельності випускників середніх шкіл на період до 2024 року для обгрунтування необхідності проведення оптимізації мережі ВНЗ країни.

Виклад основного матеріалу дослідження. Сучасна мережа вищих навчальних закладів в Україні формувалася в складних умовах соціально-економічної, політичної, духовної перебудови всього життя суспільства наприкінці XX - початку XXI століття, що безумовно, відбилося на реформуванні сфери освіти в цілому, і вищої освіти зокрема. Конкретні соціально-економічні обставини обумовили перебіг, напрямки та результати перебудови освітянської сфери. Основними чинниками, що визначали напрямки та інтенсивність перебудови вищої освіти у цей період були:

- підвищення попиту на підготовку фахівців певних спеціальностей, у першу чергу економічного, юридичного напрямів, менеджменту, маркетингу та деяких інших, відповідно до потреб ринкової економіки;

- скорочення попиту на спеціальності технічного профілю, будівництва, транспорту, сільського господарства у зв'язку зі скороченням обсягів виробництва, обумовленого економічною кризою 90-х років; 
- лібералізація законодавства у сфері вищої освіти, зокрема, надання вищим навчальним закладам права відкривати нові спеціальності не пов'язані з їх профілем і не забезпечені науково-педагогічними кадрами для підготовки фахівців за новими спеціальностями;

- пов'язана 3 цим можливість по суті безконтрольного відкриття відокремлених структурних підрозділів (філій, інститутів, технікумів, коледжів, що приєднані до ВНЗ і не мають статусу юридичної особи), які значною мірою позбавлені необхідного науковопедагогічного та матеріально-технічного забезпечення.

Це стало соціально-економічним і юридичним підгрунтям для формування нової системи організації та функціонування вищої освіти. Саме завдяки цим чинникам сформувалася принципово нова мережа вищих навчальних закладів, яка відрізняється від існуючої раніше такими ознаками:

- формальним наданням колишнім інститутам статусу університетів або академій, а середнім спеціальним навчальним закладам - статусу інститутів, коледжів тощо;

- перетворенням вищих навчальних закладів у більш багатопрофільні завдяки відкриттю нових спеціальностей, які часто не відповідають профілю та традиціям підготовки фахівців у цих ВНЗ. У першу чергу це стосується закладів освіти технічного профілю, де були відкриті спеціальності економічного, юридичного та інших напрямів;

- подрібненням та автономізацією мережі за підпорядкуванням вищих навчальних закладів. Сьогодні державні вищі навчальні заклади підпорядковані 26 міністерствам і відомствам [10];

- змінами у територіальному розміщенні вищих навчальних закладів, що наочно представлено на рисунках. Певною мірою це сприяє підвищенню доступу молоді до вищої освіти, оскільки відпали необхідність і труднощі навчання у ВНЗ, розташованих далеко від міста їі постійного проживання;

- невиправданим збільшенням кількості напрямів і спеціальностей, за якими готують фахівців у вищих навчальних закладах України [11, с.8].

Стихійне реформування мережі вищих навчальних закладів України наприкінці XX початку XXI століття було не тільки викликом часу, але й мало певні позитивні результати. Розглянемо один із таких результатів - підвищення доступу молоді до вищої освіти та збереження науково-педагогічного потенціалу вищої школи.

Проведений аналіз показав, що завдяки збільшенню кількості вищих навчальних закладів і чисельності студентів, які в них навчалися, підвищилося значення показника доступу до вищої освіти i, як результат, - «чисельність студентів у розрахунку на 100 тисяч населення». Цей показник використовується у міжнародних порівняннях для оцінки рівня доступу молоді до вищої освіти. В Україні цей показник мав тенденцію до підвищення наприкінці XX - початку XXI століття. Але наразі тенденція змінилася на протилежну. Порівняно з 2010 роком цей показник скоротився на одну третину в результаті такого ж відносного скорочення чисельності студентів. Такий взаємозв'язок чисельності студентів $\mathrm{i}$ населення свідчить, що цей показник не може характеризувати рівень доступу молоді до освіти, а лише відображає фактичний стан і напряму залежить від незалежних сукупностей.

Вважаємо, що для характеристики доступу молоді до вищої освіти необхідно використовувати два показника:

1) Показник «Прийнято до ВНЗ на денну форму навчання із осіб, що закінчили денну середню школу в поточному році», який визначає фактичну частку випускників середніх шкіл, які вступили до ВНЗ в поточному році і не характеризує доступ як можливість вступу до ВНЗ. Але такі дані відсутні в офіційній статистиці. Тому користуються співвідношенням кількості випускників поточного року і кількості прийнятих в поточному році, серед яких присутні випускники шкіл минулих років і випускників інших середніх начальних закладів, які вступили до ВНЗ.

2) Доступ, як потенційна можливість одержати вищу освіту, тобто надання державою такої можливості, характеризується співвідношенням чисельності випускників середніх шкіл 3 наявністю ліцензійних місць у вищих закладах освіти i, як варіант, з наявністю бюджетних місць. Очевидно, що скорочення кількості бюджетних місць знижує доступ до вищої освіти. 
3 огляду на вищенаведені дані, можна зробити висновок про те, що розширення мережі вищих навчальних закладів в період соціально-економічної та демографічної кризи 90-х років було певною мірою виправданим кроком. Це дозволило не тільки підвищити рівень доступності населення до вищої освіти, але й зберегти (хоч і не повною мірою) науковопедагогічний потенціал вищої школи. В першу чергу це стосується вищих навчальних закладів технічного профілю, набор на спеціальності яких у той період різко скоротився.

Також на чисельність науково-педагогічного персоналу суттєво впливає кількість ВН3, ї галузева структура, територіальне розташування. Тому питання збереження педагогічного потенціалу ВНЗ напряму пов'язане 3 тим, у яких напрямках необхідно вдосконалювати сучасну мережу вищих начальних закладів [12, с.15].

У результаті в Україні склалася певна суперечність між вимогами сучасного розвитку суспільства до фахівців і реальним рівнем їх підготовки у ВНЗ, що обумовлює необхідність реформування мережі вищих навчальних закладів.

У 90-ті роки можливість різкого збільшення чисельності студентів забезпечувалася постійно зростаючим контингентом випускників середніх шкіл, який формувався із народжених у 70-80 pp. минулого століття, коли рівень народжуваності в країні був стабільним і достатньо високим (понад 12\%). Однак поряд з цим 90-ті роки характеризуються різким падінням народжуваності, що є результатом глибокої демографічної кризи та стало причиною скорочення кількості народжених аж до 2002 року [13].

Динаміка кількості народжених в Україні у 1990-2014 рр. представлена в табл. 1.

Таблиця 1

Кількість народжених в Україні у 1990-2014 рр., тис. осіб (розраховано авторами за даними [13])

\begin{tabular}{|c|c|c|c|c|c|}
\hline Рік & $\begin{array}{c}\text { Кількість } \\
\text { народжених }\end{array}$ & $\begin{array}{c}\text { Збільшення +, } \\
\text { скорочення - } \\
\text { порівняно 3 } \\
\text { попереднім роком }\end{array}$ & Рік & $\begin{array}{c}\text { Кількість } \\
\text { народжених }\end{array}$ & $\begin{array}{c}\text { Збільшення +, } \\
\text { скорочення - } \\
\text { порівняно 3 } \\
\text { попереднім роком }\end{array}$ \\
\hline 1990 & 657,2 & - & 2002 & 390,7 & 14,2 \\
\hline 1991 & 630,8 & $-26,4$ & 2003 & 408,6 & 17,9 \\
\hline 1992 & 596,8 & $-34,0$ & 2004 & 427,3 & 18,7 \\
\hline 1993 & 557,5 & $-39,3$ & 2005 & 426,1 & $-1,2$ \\
\hline 1994 & 521,5 & $-36,0$ & 2006 & 460,4 & 34,3 \\
\hline 1995 & 492,9 & $-28,6$ & 2007 & 472,7 & 12,3 \\
\hline 1996 & 467,2 & $-25,7$ & 2008 & 510,6 & 37,9 \\
\hline 1997 & 442,6 & $-24,6$ & 2009 & 512,5 & $-14,8$ \\
\hline 1998 & 419,2 & $-23,4$ & 2010 & 497,7 & $-4,9$ \\
\hline 1999 & 389,2 & $-30,0$ & 2011 & 502,6 & 18,1 \\
\hline 2000 & 385,1 & $-4,1$ & 2012 & 520,7 & $-17,1$ \\
\hline 2001 & 376,5 & $-8,6$ & 2013 & 503,6 & $-37,7$ \\
\hline 2002 & 390,7 & 14,2 & 2014 & 465,9 & \\
\hline
\end{tabular}

Починаючи з 2006/2007 навчального року до вищих навчальних закладів почала вступати молодь народжена у 1989-1990 рр. Протягом наступних 9 років скорочення кількості народжених щорічно в середньому складало 30 тис. осіб. На початку XXI століття народжуваність змінила негативну тенденцію на позитивну, але рівня 80-х років ще не досягнуто [13].

Скорочення кількості народжених в Україні тривало до 2001 року. Це означає, що до 2018 р. включно контингент випускників середніх шкіл буде постійно скорочуватися.

У межах цього дослідження було проведено прогнозні розрахунки чисельності випускників середніх шкіл на період до 2024 року. Розрахунок майбутньої чисельності абітурієнтів (випускників середніх загальноосвітніх шкіл) проводився за формулою (1):

$$
\mathrm{A}_{\mathrm{t}}=\mathrm{N}_{\mathrm{t}-17} \times\left(\mathrm{P}_{17} \times \alpha \frac{\mathrm{t}=1}{2}\right) \times \mathrm{K}_{\mathrm{t}} .
$$


де: $\mathrm{A}_{\mathrm{t}}-$ чисельність абітурієнтів у рік $\mathrm{t} ; \mathrm{N}_{\mathrm{t}-17}$ - кількість народжених у році t-17; $\mathrm{P}_{17}-$ коефіцієнт дожиття до 17 років за таблицями смертності; $\alpha$ - постійна величина підвищення коефіцієнту дожиття; $\mathrm{t}$ - функція часу; $\mathrm{K}_{\mathrm{t}}$ - частка осіб у віці 17 років, які закінчили середню школу.

Починаючи 32012 p. коефіцієнт дожиття буде $\mathrm{P}_{18}$ у зв'язку 3 тим, що при 12-річному терміні навчання віковий інтервал школярів становить 6-18 років.

Прогноз проводився за даними Державної службі статистики України про кількість народжених у 1988-2007 pp., та чисельність учнів і випускників середніх загальноосвітніх шкіл, а також таблиць смертності [13]. В основу прогнозного розрахунку було покладено такі гіпотези:

- виходячи з того, що рівень смертності населення віком 0-17 років, починаючи з 2010 р. в Україні знаходиться на достатньо низькому рівні, не варто чекати суттєвих змін у значенні коефіцієнту дожиття дітей до віку закінчення середньої школи. У наведеному розрахунку його значення прийнято на рівні $0,99588 \pm 0,0001$;

- частка молоді, яка закінчує загальну середню школу наразі складає $72,1 \%$ від тих, хто дожив до віку закінчення школи. Таке співвідношення зберігається в країні протягом останніх 15 років і тому є підстави вважати, що суттєвих змін його значення у перспективі не очікується. Це стало основою для використання цього значення у прогнозному розрахунку.

Результати розрахунків представлені в табл. 2.

Таблиця 2

Прогнозні розрахунки потенціальної чисельності абітурієнтів ВНЗ в Україні до 2024 р. (розраховано авторами за даними [13])

\begin{tabular}{|c|c|c|c|c|}
\hline $\begin{array}{c}\text { Рік } \\
\text { народження }\end{array}$ & $\begin{array}{c}\text { Середньорічна } \\
\text { кількість } \\
\text { народжених, } \\
\text { тис. осіб }\end{array}$ & $\begin{array}{c}\text { Рік закінчення } \\
\text { школи }\end{array}$ & $\begin{array}{c}\text { Із кількості } \\
\text { народжених } \\
\text { дожили до віку } \\
\text { закінчення } \\
\text { середньої школи, } \\
\text { тис. осіб }\end{array}$ & $\begin{array}{c}\text { Чисельність учнів, } \\
\text { які закінчили } \\
\text { середню школу, } \\
\text { тис. осіб }\end{array}$ \\
\hline $1997-1998$ & 430,9 & 2015 & 430,6 & 310,0 \\
\hline $1998-1999$ & 404,2 & 2016 & 403,9 & 290,8 \\
\hline $1999-2000$ & 387,2 & 2017 & 386,9 & 278,6 \\
\hline $2000-2001$ & 380,8 & 2018 & 380,5 & 274,0 \\
\hline $2001-2002$ & 383,6 & 2019 & 383,3 & 276,0 \\
\hline $2002-2003$ & 399,7 & 2020 & 399,4 & 287,6 \\
\hline $2003-2004$ & 418,0 & 2021 & 417,7 & 300,7 \\
\hline $2004-2005$ & 426,7 & 2022 & 426,4 & 307,0 \\
\hline $2005-2006$ & 443,3 & 2023 & 442,9 & 318,9 \\
\hline $2006-2007$ & 466,6 & 2024 & 466,2 & 335,7 \\
\hline
\end{tabular}

Розрахунки свідчать про те, що скорочення чисельності випускників середніх шкіл буде продовжуватися до 2018 р., коли їх чисельність досягне 274 тисяч осіб, що складатиме 88\% від випуску 2015 р. Рівня 2015 р. буде досягнуто лише у 2022 р. Загалом за 9 років з 2009 по 2018 рік обсяг випусків загальноосвітніх навчальних закладів прогнозується на рівні 3 млн. осіб проти 4,4 млн. за аналогічний за тривалістю період з 1999 по 2008 рік.

У 2008 р. чисельність випускників середніх шкіл складала у розрахунку на один вищий навчальний заклад I-IV рівнів акредитації 500 осіб, на один заклад III-IV рівнів акредитації - 1250 осіб. У табл. 3 наведено дані про чисельність випускників середніх шкіл у розрахунку на один вищий навчальний заклад у 2010-2024 pp. за умов збереження існуючої мережі вищих навчальних закладів в країні. 
Таблиця 3

Чисельність випускників середніх шкіл у розрахунку на 1 ВНЗ в Україні у 2010-2024 рр., осіб (розраховано авторами за даними [13])

\begin{tabular}{|c|c|c|c|c|c|}
\hline \multirow{2}{*}{ Рік } & \multicolumn{2}{|c|}{$\begin{array}{c}\text { Випускники середніх шкіл } \\
\text { розрахунку на 1 ВН3 }\end{array}$} & \multirow{2}{*}{ Рік } & \multicolumn{2}{|c|}{$\begin{array}{c}\text { Випускники середніх шкіл у } \\
\text { розрахуну на 1 ВН3 }\end{array}$} \\
\cline { 2 - 3 } \cline { 5 - 6 } & I-IV рівнів & III-IV рівнів & & I-IV рівнів & III-IV рівнів \\
\hline 2010 & 441 & 1100 & 2018 & 311 & 776 \\
\hline 2011 & 414 & 1034 & 2019 & 313 & 782 \\
\hline 2012 & 402 & 996 & 2020 & 326 & 815 \\
\hline 2013 & 392 & 978 & 2021 & 341 & 852 \\
\hline 2014 & 372 & 927 & 2022 & 348 & 870 \\
\hline 2015 & 352 & 878 & 2023 & 362 & 903 \\
\hline 2016 & 330 & 824 & 2024 & 381 & 951 \\
\hline 2017 & 316 & 789 & & & \\
\hline
\end{tabular}

Порівняння чисельності випускників середніх шкіл з ліцензованими обсягами набору у вищі навчальні заклади показує, що вже у 2009 р. це співвідношення складало $377: 400=0,943$, і конкурс забезпечувався за рахунок випускників минулих років. Якщо у 1990 р. із загальної чисельності випускників середніх шкіл тільки 49\% вступили до вищих навчальних закладів, то у 2000 р. вже 78\%, а з 2005 р. чисельність зарахованих до ВН3 III-IV рівнів акредитації перевищувала кількість випускників шкіл відповідного року за рахунок випускників минулих років [14, с.42-52].

Таким чином, за прогнозними розрахунками, у 2018 р. співвідношення між випускниками шкіл і ліцензованими обсягами скоротиться до 0,685 , а чисельність випускників шкіл у розрахунку на один вищий навчальний заклад знизиться з 470 у 2009 р. до 311 у 2017 р.

Розрахунок показує, що для повернення до конкурсу на рівні 2009 р. необхідно до 2018 р. скоротити на одну третину кількість вищих навчальних закладів.

Також варто відмітити, що оптимізація мережі вищих навчальних закладів в Україні передбачає врахування розміщення навчальних закладів по території країни. Зазначимо, що відкриття нових навчальних закладів і, зокрема, відокремлених підрозділів ВН3 у 1990-х роках та на початку XXI століття обгрунтовувалося наявністю не тільки потреби у фахівцях певного профілю, але й наявністю необхідної чисельності абітурієнтів. Проведені у цьому дослідженні розрахунки показують, що скорочення чисельності абітуріснтів відбудеться в усіх областях України, а це, у свою чергу, сприятиме об'єднанню та ліквідації невеликих навчальних закладів в окремих областях.

Висновки i перспективи подальших розробок. Таким чином, на підставі проведеного дослідження можна зробити висновок про те, що якщо наразі обсяг прийому до вищих навчальних закладів III-IV рівнів акредитації перевищує чисельність абітурієнтів у 6 областях (великих вузівських центрах країни), то у 2018 р. таке перевищення буде спостерігатися у 13 областях. Результатом цього стане посилення тяжіння абітурієнтів до великих вузівських центрів і значне скорочення вступу до вищих навчальних закладів за місцем проживання. А якщо врахувати, що серед абітурієнтів до 50\% - контрактники, то це об’єктивно призведе до ліквідації в таких областях вищих навчальних закладів i, в першу чергу, відокремлених підрозділів головних ВНЗ.

Але навчання студентів розпорошено між великою кількістю ВН3, що визначає назрілу необхідність суттєвого скорочення державних вищих навчальних закладів. Якщо прийняти за стандарт середній розмір ВНЗ в перелічених країнах Європи, то можна розрахувати наскільки необхідно скоротити кількість державних вищих навчальних закладів в Україні, щоб досягти європейського рівня.

Поділивши чисельність студентів у ВНЗ державної форми власності III-IV рівнів акредитації в Україні (1438 тисяч) на середній розмір університету в названих країнах (19,4 тисячі), отримаємо кількість університетів такого розміру, яка необхідна Україні (75). 
Наведені розрахунки дозволили дійти висновку про необхідність суттєвого скорочення вищих навчальних закладів, а також їх перепрофілювання з урахуванням сучасних вимог.

Рішення цієї проблеми потребує наукового обгрунтування з урахуванням множини факторів економічного, соціального, психологічного характеру, які визначають сучасний стан функціонування вищої освіти та можливих позитивних і негативних наслідків. Не останнє місце в цьому переліку займає історичний фактор, який, вважаємо, суттєво впливає на шляхи такої реформи.

\section{Лimepamypa}

1. Науково-освітній потенціал нації: погляд у ХХІ століття / В. М. Литвин, В. П. Андрущенко та ін. - К.: Навч. книга. - Кн. 3: Модернізація освіти, 2003. - 943 с.

2. Вахович I. М. Дослідження теоретичних аспектів доцільності процесу укрупнення ВНЗ в Украйні / І. М. Вахович, Ю. В. Волинчук // Актуальні проблеми економіки. - 2010. № 2 (104). - C. 101-107.

3. Кремень В. Г. Укрупнення ВНЗ підвищить якість освіти [Електронний ресурс] / В. Г. Кремень. - Освітній портал (27.02.2014). - Режим доступу: www.osvita.org.ua.

4. Сфрремов В. Оптимізачія ВНЗ в Україні як необхідна умова підвищення їх конкурентоспроможності / В. Сфрремов // Вища школа. - 2014. - № 3-4. - С. 73-83.

5. Корольова Т. С. Ефективність використання наукового потенціалу вищого навчального закладу / Т. С. Корольова // Вісник соиіально-економічних досліджень: зб. наук. праць. Одеса: ОДЕУ. - 2007. - Вип. 29. - С. 93-96.

6. Корольова T. С. Інтеграчія вищої освіти Украӥни до європейського освітянського простору в умовах глобалізачії / T. С. Корольова // Начіональна економіка у сучасній глобальній економічній системі: механізми функціонування, динаміка, економічна безпека: Матеріали міжнар. наук.-практ. конф. (Полтава, 23-24 квітня 2010 р.). Полтава: ПУСКУ, 2010. - С. 28-34.

7. Корольова Т. С. Особливості інновачійних прочесів у сфері вищої освіти / Т. С. Корольова // Науковий вісник Буковинської держ. фінансової академї (Серія «Економічні науки»). Чернівиі: Технодрук, 2009. - Вип. 2 (15). - C. 78-84.

8. Подгорный А. 3. Научные кадры как составляющая инновационного развития экономики / A. 3. Подгорный, Т. С. Королева // Подготовка научных кадров высшей квалификации в условиях инновационного развития экономики. Региональные, межрегиональные и международные аспекты: Материаль Междунар. науч.-практ. конф. (Минск, 30 мая 1 июня 2007 г.). - Минск: ГУ «БелИСА», 2007. - С. 61-64.

9. Підгорний A. 3. Проблеми формування контингенту абітурієнтів ВНЗ в умовах сочіально-демографічної кризи / А. 3. Підгорний, Т. С. Корольова // Управління підприємством: проблеми та иляхи їх вирішення: Матеріали IV Міжнар. наук.-практ. конф. (Севастополь, 1-3 жовтня 2009 р.). - Донецьк: ДонНУЕТ, 2009. - С. 153-156.

10. Квіт С. М. Реформування системи освіти є пріоритетним завданням: Виступ 17.05.2014 p. [Електронний ресурс]. - Режим доступy: sergiy_kvit_zaraz_mi_mogemo_priymati_horoshi_ zakoni_zminyuvati pravila_gri_i_mi tsim_koristue mosya_ $1939 \overline{49} 0 . \bar{h} t m l$.

11. Пономаренко В. Проблеми підготовки наукових кадрів / В. Пономаренко // Вища школа. 2012. - № 2. - C. 7-19.

12. Степко М. Світові тенденції розвитку вищої освіти та проблеми забезпечення якості й ефективності вищої освіти в Украӥні / М. Степко // Вищза шккола. - 2013. - № 7. - С. 13-22.

13. Населення Украӥни за 1990-2014 рр.: демографічний щзорічник [Електронний ресурс] // Державна служба статистики Украӥни. - Режим доступу: http://ukrstat.org/uk/druk/ publicat/Arhiv_u/01/Arch_ukr_zb.htm.

14. Основні показники діяльності вищих навчальних закладів України на початок 2014/2015 навчального року: статистичний бюлетень. - K: Державна служба статистики України, 2015. - 169 с. 


\section{References}

1. Litvin, V. M., Andrushchenko, V. P. and other (2003), Scientific and educational potential of the nation: foresight into the XXI century [Naukovo-osvitnii potentsial natsii: pohliad u XXI stolittia], Kyiv: Training book, B. 3: Modernization of Education, 943 p. (ukr)

2. Vakhovych, I. M., Volynchuk, Yu. V. (2010), The research of theoretical aspects of the feasibility of consolidation process of higher education institutions in Ukraine [Doslidzhennia teoretychnykh aspektiv dotsilnosti protsesu ukrupnennia VNZ v Ukraini], Actual problems of economy, No. 2 (104), pp. 101-107 (ukr)

3. Kremen, V. H. (2014), Consolidation of higher education institutions will improve the quality of education [Ukrupnennia VNZ pidvyshchyt yakist osvity], available at: www.osvita.org.ua (ukr)

4. Yefremov, V. (2014), Optimization of higher education institutions in Ukraine as a necessary condition of their competitiveness improvement [Optymizatsiia VNZ v Ukraini yak neobkhidna umova pidvyshchennia yikh konkurentospromozhnosti], Vyshcha shkola, No. 3-4, pp. 73-83 (ukr)

5. Koroleva, T. S. (2007), The efficiency of higher education institution scientific potential [Efektyvnist vykorystannia naukovoho potentsialu vyshchoho navchalnoho zakladu], Socioeconomic research bulletin: Coll. of scientific works, OSEU, Odessa, Vol. 29, pp. 93-96 (ukr)

6. Koroleva, T. S. (2010), Integration of higher education of Ukraine into the European educational space in the conditions of globalization [Intehratsiia vyshchoi osvity Ukrainy do yevropeiskoho osvitianskoho prostoru $v$ umovakh hlobalizatsii], The national economy in today's global economic system, mechanisms of dynamics, economic security: Materials of international scientific and practical conference (23-24 April, 2010), Poltava, PUSKU, pp. 28-34 (ukr)

7. Koroleva, T. S. (2009), Features of the innovative processes in higher education [Osoblyvosti innovatsiinykh protsesiv u sferi vyshchoi osvity], Scientific Bulletin Bukovyna State Finance Academy: Economics Series, Chernivtsi, Tehnodruk, Vol. 2 (15), pp. $78-84$ (ukr)

8. Podhornyj, A. Z., Koroleva, T. S. (2007), Scientific personnel as part of the innovation development of economy [Nauchnye kadry kak sostavlyayushchaya innovatsionnogo razvitiya ekonomiki], Preparation of highly qualified scientific personnel in the conditions of innovative development of economy. Regional, inter-regional and international aspects: Materials of the International scientific and practical conference (Minsk, 30 May - 1 June 2007), Minsk, GU BelISA, pp. 61-64 (rus)

9. Podgornyj, A. Z., Koroleva, T. S. (2009), The problems of higher education institution students contingent formation in terms of socio-demographic crisis [Problemy formuvannia kontynhentu abituriientiv VNZ $v$ umovakh sotsialno-demohrafichnoi kryzy], Enterprise Management: problems and ways of their solutions: Materials of IV International Scientific and Practical Conference (Sevastopol, 1-3 October, 2009), DonNUET, Donetsk, pp. 153-156 (ukr)

10. Kvit, S. M. (2014), Reformation of education system is a priority task [Reformuvannia systemy osvity ye priorytetnym zavdanniam], available at: $w w w . s e r g i y \_k v i t z a r a z$ mi_mogemo_priymati_ horoshi_zakoni_zminyuvati_pravila_gri_i_mi_tsim_koristue_mosya_19394900.html (ukr)

11. Ponomarenko, $\bar{V}$. (2012), The problems of scientific personnel training [Problemy pidhotovky naukovykh kadriv], Vyshcha shkola, No. 2, pp. 7-19 (ukr)

12. Stepko, M. (2013), Global development trends of higher education and the problem of providing quality and efficiency of higher education in Ukraine [Svitovi tendentsii rozvytku vyshchoi osvity ta problemy zabezpechennia yakosti i efektyvnosti vyshchoi osvity $v$ Ukraini], Vyshcha shkola, No. 7, pp.13-22 (ukr)

13. The population of Ukraine as for 1990-2014: demographic yearbook [Naselennia Ukrainy za 1990-2014 rr.], State Statistics Service of Ukraine, available at: http://ukrstat.org/uk/druk/ publicat/Arhiv_u/01/Arch_ukr_zb.htm (ukr)

14. The main performance indicators of higher education institutions in Ukraine at the beginning of 2014/2015 academic year (2015) [Osnovni pokaznyky diialnosti vyshchykh navchalnykh zakladiv Ukrainy na pochatok 2014/2015 navchalnoho roku], Statistical Bulletin, State Statistics Service of Ukraine, Kyiv, 169 p. (ukr) 